\title{
Western Canadiana at McGill University: \\ The Lande and Arkin Collections
}

\section{by Peter F. McNally}

\begin{abstract}
Canadiana emerged as a collecting focus for McGill even before the opening of Redpath Library in 1893. At first, the emphasis was local — Quebec, including New France - reflecting a lack of concern for other parts of the country, typical of collections at the time. Only in the second half of the twentieth century did this situation change when a vogue for collecting Canadiana spread across the nation to both large and smaller libraries; larger institutions, already possessing strength, extended the depth and breadth of their rare book collections. In the case of McGill, during the '60s and '70s, Western Canadiana became a focus for new collecting. This article recounts how McGill developed an important Western Collection-and examines the individuals and circumstances responsible for its acquisition, along with a profile and evaluation of its contents. Particular attention is paid to two collectors - Lawrence Lande and Nathan Arkin - two librarians Richard Pennington and Jobn Archer - and one antiquarian book dealer - Bernard Amtmann. The methodology used for evaluating the Lande and Arkin Western Canadiana Collections may prove helpful to other researchers.
\end{abstract}

\section{RESUMÉ}

Même avant l'ouverture de la Bibliothèque Redpath en 1893, McGill portait déjà une attention particulière à la collection de publications canadiennes. Au début, le volet local -- le Québec, incluant la Nouvelle-France -- était accentué, démontrant un manque d'intérêt pour le reste du pays qui était typique des collections de l'époque. Cette situation n'a commencé à changer que dans le seconde moitié du vingtième siècle, quand l'acquisition de publications canadiennes est entrée en vogue à travers le pays, à la fois dans les petites et les grandes bibliothèques. Ces dernières, ayant déjà des fonds documentaires solides dans ce domaine, ont élargi et approfondi leurs collections de livres rares. Dans le cas des collections de McGill, l'ouest canadien est devenu un nouveau pôle d'intérêt durant les années 60 et 70. Cet article décrit le développement à McGill d'une importante collection ouest-canadienne et examine les personnes et les circonstances responsables pour l'acquisition de cette collection, dont le contenu est également résumé et évalué. Une attention particulière est portée à deux collectionneurs - Lawrence Lande et Nathan Arkin - à deux bibliothécaires - Richard Pennington et John Archer - et à un libraire antiquaire - Bernard Amtmann. La méthodologie utilisée pour évaluer les collections Lande et Arkin de publications ouest-canadiennes pourrait se démontrer utile pour d'autres chercheurs.

A lthough the Canadiana collections of the McGill University Library began showing strength in the late $19^{\text {th }}$ century, Western Canadiana as a specialized collecting focus for the Library began only in the 1960s. This study considers the circumstances and the five men who propelled McGill into this subset of Canadiana: Bernard Amtmann, John Archer, 
Nathan Arkin, Lawrence Lande, and Richard Pennington - two collectors, two librarians, and one antiquarian book dealer. Also considered is the profile of Western Canadiana in the Lande and Arkin Collections, including strengths and weaknesses.

One of the great success stories of Canadian librarianship of the past 50 years has been the development of outstanding Canadiana collections in the country's libraries. Prior to that, the significant collections were mostly in foreign institutions such as Harvard, the John Carter Brown Library, the Library of Congress, the British Library, and the Bibliothèque nationale de France. Thanks to the efforts of librarians and private collectors, virtually every Canadian academic library and many public and specialized libraries now have Canadiana collections that range from being regionally significant to internationally important.

When it comes to Western Canadiana collections, as a specialized subset within general Canadiana, it becomes rather more difficult to specify either their strength or the extent to which they have developed. The purpose of this paper will be, therefore, to undertake a case study of McGill's Western Canadiana collection: the peopleand circumstances surroundingits creation, how it came to the University, an evaluation of its nature, strength, and weaknesses, along with suggestions on a methodology for evaluating the comparative strengths and weaknesses of other Western Canadiana collections. It is hoped that this study may inspire some future researcher to undertake a detailed comparison of McGill's collection with other similar collections. ${ }^{1}$

To begin, what constitutes "Western" Canadiana? Is it only material relating narrowly to the three Prairie provinces? Is it material relating to both the Prairies and British Columbia? What about the Yukon and the Western Arctic? For the purposes of this paper, the broadest definition of "Western" has been used; all parts of the country west and north-west of Ontario.
As for where Western Canadiana can be found, the Directory of Special Collection of Research Value in Canadian Libraries $(1992)^{2}$ and a variety of additional sources must be consulted. As was expected Western Canadian universities have notable collections: The Adam Shortt Collection at the University of Saskatchewan has 17,000 monographs that includes much Western Canadiana; the A.C. Rutherford Collection of Western Canadiana at the University of Alberta has 5,500 monographs; the Western Canadiana Collection of Rare Books and Pamphlets at the University of Manitoba has between 2,500 and 3,000 titles; the Doukhobor and the HowayReid Collections at the University of British Columbia are largely concerned with the Canadian West and have respectively 400 and 50,000 monographs; and the Margaret P. Hess Collection $^{3}$ and the Arctic Institute Library ${ }^{4}$, with their strongly Western Canadian focus, both at the University of Calgary, have respectively 11,000 and 50,000 items. The Library of the British Columbia Provincial Archives ${ }^{5}$ in Victoria, and the Glenbow-Alberta Institute Library in Calgary ${ }^{6}$ have respectively 68,000 and 75,000 volumes with strong emphases upon the Canadian West. The Western legislative libraries and several public libraries also have significant collections.

What of Western Canadiana in the Central and Atlantic provinces? The Davidson Collection $^{7}$ at Mount Allison University lists 146 titles of Western interest in its catalogue (1991). The Isaac Burpee Western Collection at the University of New Brunswick has between 600 and 700 titles relating to the Pacific North West that include some Canadian items. ${ }^{8}$ The John Archer Western Canadiana Collection at the Université de Montréal has approximately 2,000 books, pamphlets and off-prints. ${ }^{9}$ The Ernest Thompson Seton Collection at Trent University, Peterborough Ontario, contains 250 monographs. Although little Western material is listed in the published catalogues of pre-Confederation titles in the Metropolitan 
Toronto Public Library's Canadiana collection, ${ }^{10}$ a great deal of relevant material can be located there. ${ }^{11}$ Both the Fisher Rare Book Library at the University of Toronto and the National Library of Canada in Ottawa contain significant Western material, inter alia, even if no specifically designated collections have been developed.

This brings us inevitably to McGill University. As nearly as can be determined, it has the most significant collection of Western Canadiana in Central and Eastern Canada. Indeed one might speculate that it has one of the country's few Canadiana collections that possesses strength transcending provincial or regional boundaries. Canadiana was strong at McGill even before the opening of Redpath Library in 1893. This strength was greatly enhanced when Lawrence Lande made his first donation of rare Canadian materials in 1963. Between then and 1975 he gave, sold, or assisted in the purchase of Canadian collections which today number about 12,000 items, of which approximately three-quarters relate primarily to New France and Quebec (Lower Canada before Confederation), and onequarter or 3,000 items to the West and Arctic. Ontario (Upper Canada) and Atlantic Canada have received only nominal representation in the collections. Since the opening of McLenann Library, in 1969, the collections have been supervised by their own librarian, and housed on the Library's fourth floor, close to the general Canadian history collection. For nearly 30 years, the Lande Room was separated by four stories from the Department of Rare Books and Special Collections, to which it was administratively attached but located on the Library's street floor level. In the summer of 1997, the Department was relocated to the fourth floor, and the Lande Room was enlarged to become the reading room of the Division of Rare Books and Special Collections - as it is now called - whose Chief Curator serves as Lande Librarian. Together with the University's other collections, the Lande Collections constitute one of the country's most important resources for the study of Canada. ${ }^{12}$
The explanation of how the Lande Canadiana Collections came to McGill must begin by discussing five major figures: Lawrence Lande, Nathan Arkin, Bernard Amtmann, Richard Pennington, and John Archer - two collectors, an antiquarian book dealer, and two librarians one of whom became a university president. These five men have all made enormous contributions towards the development of libraries, bibliography, and book culture whose beneficial influence will be felt as long as Canada continues to be a field of study and research.

Lawrence Montague Lande (pronounced Landy) was born in Ottawa, Ontario, on 11 November $1906 .{ }^{13}$ His father, an immigrant from Lithuania, was a businessman as were his sons. At the age of six months, young Lande moved with his family to Montreal where he lived until his death on 11 August 1998. After graduating from McGill with a B.A. in 1928, he received a law degree from the Université de Montréal, and a Diploma in Philosophy from Université de Grenoble (France). Although he worked as a notary public, a businessman - running a Buick car dealership - and an associate in his family's financial enterprises, he defined himself as a bookman and writer.

His collecting began during boyhood and continued until his death. His first significant collection was of William Blake which he gave to McGill in $1953 .{ }^{14}$ At this point, Bernard Amtmann and Richard Pennington began encouraging Lande's interest in collecting Canadian poetry and assisted in the publication of his appreciation Old Lamps Aglow (1957). ${ }^{15}$ Over time, Lande became determined to create a lasting monument: not only would he gather collections, notable for their exceptionally fine physical quality, but he would describe them in published catalogues and have them housed in their own room with period furniture. McGill University would eventually assist in fulfilling this vision and would also grant him an honorary doctorate in 1969. Four catalogues of his 
Canadiana collections at McGill were published. In his later years, through gift and sale, other collections also went to the National Library in Ottawa. Published catalogues described these collections and others still in his possession when he died; $;^{16}$ yet other collections were described in unpublished catalogues.

By any standard, Lawrence Lande was an important bibliophile, bibliographer, collector of Canadiana, and benefactor of libraries. His support of a wide range of other philanthropic and voluntary associations was equally notable. $\mathrm{He}$ also engaged in numerous other activities such as composing music, and writing books and poetry. In the McGill online catalogue he has 33 main author entries. He was a very colourful figure, tall and distinguished looking, who enjoyed the spotlight. If imitation is the sincerest form of flattery, Lawrence Lande has been greatly flattered. Both the Melzack Collection at the Université de Montréal and the Davidson Collection at Mount Allison University were given on the understanding that they would also receive Lande-style designated rooms and published catalogues. ${ }^{17}$

The second major figure in this story is Nathan Arkin (1906-1988), born in Winnipeg of a father who immigrated from the Imperial Russian sector of Poland. ${ }^{18}$ Except for a few years spent in childhood with his family in Calgary, he lived entirely in Winnipeg. His education ended early when he began working in his family's automobile supply business. Friends and family agree that his major concern in life was not business, but rather history and scholarship. This concern may have been inherited from his father Harry Arkin (1867-1943), whose book Ethics as Legislation ${ }^{19}$ was published posthumously in 1945. Nathan Arkin was a founding member of the Jewish Historical Society of Western Canada, an active member of the Manitoba Historical Society, and served on the Board of Governors of the Manitoba Museum of Man and Nature. $\mathrm{He}$ is generally remembered as an intelligent, kindly, and self-effacing man who shunned the limelight, which made him very different from Lawrence Lande who always enjoyed public recognition of his achievements.

Arkin's collecting career began in the late 1940s when some early Manitoba pamphlets, rescued from a house being demolished in Winnipeg, were brought to his attention. They so caught his imagination that he developed a virtual obsession for collecting the printed heritage of Manitoba and eventually of all Western Canada. Arkin's son speaks of his father spending nights and weekends on his collection, which was housed primarily in the basement but could be seen throughout the house. Major concerns of the collection, his son recalls, were Manitoba, the fur trade, and related activities.

Arkin's approach to collecting, along with his knowledge of Western Canadian history, was self-taught. He availed himself of travelling opportunities occasioned by automobile conventions to scout for books, and read A.B.Bookman assiduously. By the 1960 s the value of his collection, the cost of adding new titles, and the difficulty of housing them, were beginning to worry him. In addition, with typical humility, he was becoming increasingly aware of his own lack of historical training while at the same time realizing the potential benefit to historians of the collection - particularly if housed in an accessible institution. The collection's importance was underlined by Bruce Peel (19161998) mentioning it in the Preface to the 1963 Supplement of his Bibliography of the Prairie Provinces. ${ }^{20}$ Indeed Arkin is one of the few private collectors whom Peel mentions at any length and gives as a location. As a result, by the early 1960 s Arkin had decided to sell his books and employ Bernard Amtmann as his agent.

At this point we must discuss our third major figure, Bernard Amtmann (1907-1979) ${ }_{+}^{21}$ Born in Vienna, he fled Austria in 1938, one step ahead of the Nazis. He spent the war years in France first as a soldier, then as a member of the 
underground - the head of a commando unit engaged in sabotage. After the war he began dealing in books, which continued following his 1947 arrival in Canada - the first three years being spent in Ottawa. In 1950 he moved to Montreal where he lived for the rest of his life. During the next 29 years he became Canada's most colourful and well-known antiquarian book dealer. In addition to publishing articles, pamphlets, bibliographies, and sales catalogues, he operated Montreal Book Auctions. His polemics, castigating Canadians for being insufficiently concerned about their printed and archival heritage, were widely noted. Virtually every private and institutional collector of Canadiana, at home and abroad, bought antiquarian books and manuscripts from him. In addition, he helped broaden the field by encouraging new collectors of Canadiana including Lawrence Lande.

Richard Pennington is the fourth major figure in this story. ${ }^{22}$ Born in Rugby, England, on 6 September 1904, he earned a B.A. from the University of Birmingham in 1924 and a Library Diploma from the University of London in 1934. After living in Australia from 1926 to 1930 he returned to England where he became a librarian and a political activist, opposed to appeasement of Nazi Germany, before returning to Australia as Head Librarian of the University of Queensland in 1939. In 1946 he came to McGill, and served as University Librarian from 1947 to 1964 . Upon retiring in 1965, he moved to France where he lived until returning to Montreal shortly before his death on 1 May 2003. Although his tenure as University Librarian was controversial for reasons that have been discussed elsewhere, it had significant achievements such as the construction of the 1953 wing to McGill's Redpath Library. In 1960, Pennington published Peterley Harvest ${ }^{23}$ a slim volume that has been variously labelled a hoax, a minor classic, and a literary and autobiographical experiment, around which controversy and curiosity continue to swirl.
Above all else, Richard Pennington must be considered a great bibliophile, as is amply demonstrated in his monumental study of the great 17th century engraver Wenceslaus Hollar. ${ }^{24}$ He developed great research collections for McGill, in fields such as Napoleon and Printing History. Important private collectors and benefactors were encouraged, including William Colgate and Lawrence Lande. After giving McGill his William Blake collection in 1953, Lande had his interest in Canadiana encouraged by Pennington, who involved himself in many of Lande's book and manuscript buying projects first in poetry and then in general Canadiana. Like Amtmann, Pennington assisted in the publication of Old Lamps Aglow (1957) even having his office handle its printing, sale, and publicity. ${ }^{25}$ Otherwise, no evidence of any connection between Amtmann and Pennington has been observed in their papers. Although Canadiana held little personal interest for Pennington, his positive role in the Lande Canadiana Collections coming to McGill must be fully acknowledged.

The fifth major figure is John Archer, who was born in Saskatchewan on 11 July 1914 and died there on 5 April 2004. Due to the Great Depression and World War II, his education was interrupted; like Bernard Amtmann, he became a commando during the war. ${ }^{26}$ Upon peace being restored, Archer returned to Canada and by 1949 had earned a B.A. and M.A. in history from the University of Saskatchewan and a Bachelor of Library Science from McGill. During the 1950s and early 1960s he served as Legislative Librarian and Provincial Archivist of Saskatchewan as well as being Assistant Clerk of the Legislative Assembly. In 1956 he began buying and selling books on behalf of the Legislative Library through Amtmann; over time, their transactions evolved into an exchange account. ${ }^{27}$ In 1969 , he received his Ph.D. in History from Queen's University (Kingston, Ontario). From 1970 to 1976, he shepherded the Regina Campus of the University of Saskatchewan into becoming the University of Regina as Principal of the first and President of 
the second. Among his many publications, he was the co-ordinating editor of Prime Minister John Diefenbaker's memoirs. ${ }^{28}$ The important years from our vantage point were 1964-1967 when he served as the first Director of Libraries at McGill University, in succession to Richard Pennington, the last University Librarian. Archer was brought to $\mathrm{McGill}$ to reform its libraries and reconstitute them into an integrated system.

These five men had much in common but also much not in common. All were book men who appreciated the importance of Canadian history, culture, archives and publications. Three were university graduates, but Arkin and Amtmann were not. Three were born in Canada, but Amtmann and Pennington were not. Three were Jewish, wonderful examples of that community's great contribution to Canadian books, culture, and libraries; John Archer was an Anglican and Richard Pennington a Quaker. Lande and Arkin were businessmen - both in the automobile industry -whose major interests were in collecting and culture; both did much of their buying through Amtmann. Archer and Pennington were scholar librarians much interested in rare book research collections. Archer and Lande had professional relationships with Amtmann going back to the early 1950s; in time, Archer and Amtmann became close personal friends with a shared love of football. In addition, Archer was rumoured to be Amtmann's silent partner in his antiquarian book business. Amtmann and Pennington would appear to have had only a peripheral relationship. Amtmann, Lande and Archer had a flair for publicity and being in the limelight; Pennington alternated between seeking and avoiding personal publicity. Arkin avoided publicity as much as possible. Three were Easterners, while Archer and Arkin were Westerners.

The crucial factor in this story is that John Archer, a Westerner, was briefly at McGill in the mid-1960s when Nathan Arkin was trying to dispose of his Western Canadiana collection and just after Lawrence Lande had made his first gift of Canadiana. Archer's love of Canada, his belief in the need to preserve the nation's cultural heritage, and his great political and administrative skill were undoubtedly responsible for bringing the Arkin Collection to McGill and maintaining Lande's commitment to the University. Of course, the strong support of other McGill officials such as Principal H. Rocke Robertson and Dean Stanley Frost, Chairman of the Library Committee, was crucial.

The first Lande Collection came to McGill as a gift by an agreement signed on 20 December $1963 .{ }^{29}$ Of the 2,328 entries listed in its catalogue, 607 relate to the West and North. ${ }^{30}$ The second collection was bought by McGill for $\$ 100,000$ through an agreement signed on 24 May 1972. Of the 2,541 entries listed in its catalogue, 245 relate to the West and Arctic. ${ }^{31}$ The third and fourth collections were acquired for $\$ 75,000$ by an agreement signed on 27 June 1975 . Of the 164 titles listed in the catalogue of the third collection only 153 came to McGill, the other 11 went to the National Library; none of the titles relate to the West. ${ }^{32}$ Of the 413 items listed in the catalogue of the fourth collection only 276 came to McGill, of which approximately 150 relate to the West; the remaining 137, including Pacific NorthWest coast materials, went to the National Library. ${ }^{33}$

The four Lande Collections brought to McGill 5,298 rare Canadian titles, mostly preConfederation, of which approximately 1,000 relate to the West and Arctic. Much of the Arctic material is Western; only through a separate project can the proportion relating to the Eastern Arctic be determined. In addition, both Lande and McGill placed additional titles in the Lande Room, of which the most significant is the Arkin Collection. In combination with Lande's Western titles, it accounts for McGill's great strength in Western Canadiana.

The Amtmann Papers in the National Library of Canada provide a fascinating insight into the purchase of the Arkin Collection: The convoluted 
path by which it came to McGill, the interaction among four of this story's major figures, and the wily negotiating skills of Bernard Amtmann. On 23 February 1962 Amtmann presented Arkin with a brief statement evaluating his collection at $\$ 46,869 .{ }^{34}$ A year and one-half later on 3 September 1963, Amtmann agreed to act as the agent for selling the collection at $\$ 45,000$ in return for a 10 percent commission. The papers corroborate the impression of Arkin's friends and family that he wished to sell the collection as a coherent unit rather than as individual titles or sections, that he wanted it to remain in Canada, and that attempts to sell it to the University of Manitoba had proven unsuccessful. In addition, the papers show that during the year preceding the sale, Arkin continued buying large numbers of titles from Amtmann. Whether any of these titles became part of the collection purchased ultimately by $\mathrm{McGill}$ can be determined only through a separate project.

That Amtmann did not even bother approaching McGill during 1963 may have been due to his realizing that Richard Pennington's tenure as University Librarian was coming to an end and that a successor was being sought. Rather, he targeted the University of Alberta as the appropriate destination for Arkin's Collection. On 2 September 1963 - the day before confirming the agreement to become Arkin's agent - Amtmann wrote to Bruce Peel, the Head Librarian - possibly at his request - offering the collection to the University for $\$ 60,000$, voicing the hope that the collection would remain in Canada, and intimating that there was a competing offer from another Canadian university. As with most of Amtmann's communications during these negotiations, duplicate messages were sent by telegraph and mail. Over the next year Amtmann was in regular correspondence with Peel and Walter $\mathrm{H}$. Johns, President of the University. As to there being offers initially from other institutions, no corroborating evidence can be found.
Typescript lists of the collection, available in the files of the Division of Rare Books and Special Collections, McLennan Library, appear to have provided the bibliographical information used by Alberta and other potential purchasers in evaluating the collection. In addition, Bruce Peel had personally inspected the collection some years earlier while working on the 1963 supplement to his "Prairie bibliography" On 10 October Peel told Amtmann that the price for the 2,500 titles was too high, that much of the collection duplicated Alberta's holdings, and that the University would be interested in buying only part of the collection. Amtmann responded by lowering the price to $\$ 50,000$ on 15 October, to which Peel replied on 30 October that it was still too high. On 22 November, Dr. Johns said that Alberta was prepared to pay $\$ 30,000$ for the collection. Negotiations dragged on over the next few months, with suggestions from both sides on how to reach a compromise. On 27 February 1964 Amtmann told Arkin that Alberta would not meet his conditions of sale., By April, however, negotiations had reopened and Arkin informed Amtmann that Alberta was sending someone to Winnipeg to inspect the collection. Other interested parties began making enquiries including T.R. McCloy of Calgary's Glenbow Foundation, and Lawrence Lande. On 12 June, Amtmann wrote Bruce Peel an intriguing letter in which he offered to sell the Arkin duplicates at a 25 percent commission should Alberta buy the collection. ${ }^{36}$ This offer appears, in retrospect, to have been a harbinger of the agreement that was eventually concluded.

Another harbinger of the eventual agreement appeared in a 13 February 1964 note from John Archer to Amtmann, thanking him for his good wishes, assuring him that their business relations would continue in his new position, and saying that they would meet soon in Montreal. ${ }^{37}$ Shortly after assuming his new position as Director of Libraries at McGill, Archer sent a letter to Amtmann dated 29 July returning a copy of the Arkin catalogue borrowed previously by 
Lawrence Lande. ${ }^{38}$ Archer and Lande were clearly impressed with the collection because Amtmann issued Arkin with a 10 percent commission invoice of $\$ 4,300$ on 26 August 1964 for its sale to McGill; $;^{39}$ whether Arkin ever appreciated that Lande assisted financially in the purchase is uncertain. One can only guess at Amtmann's satisfaction at being able to tell Walter $\mathrm{H}$. Johns on 4 September that McGill had bought the collection, when replying to yet another letter of refusal from Alberta. As for the story that a few days after signing the sale agreement, a distraught Nathan Arkin received an offer of $\$ 70,000$ from the University of Texas, no corroborating evidence has been found. In any event, Amtmann and Archer went personally to Winnipeg, at Lande's request, to pack the Arkin books for shipment to Montreal. ${ }^{40}$

What was the nature of the agreement that Amtmann, Lande, and Archer made with Arkin? As Amtmann's commission was 10 percent, one may assume that the sale price was $\$ 43,000$, only $\$ 2,000$ less than Arkin was seeking. It is possible, however, that the sale price may have actually been $\$ 46,000$, as an additional payment of $\$ 3,000$ for supplementary material is mentioned by Amtmann in a letter to Arkin of 15 May $1965 .{ }^{41}$ The total payment was spread over four years between 1964 and 1967. In return, Arkin had the satisfaction of knowing that his collection would be kept together in a Canadian institution. This did not mean, however, the end of his Canadiana career as the Amtmann papers record buying and selling up to 1978, the Reid Collection being probably Arkin's most significant sale. ${ }^{42}$

As for Amtmann, Lande, and Archer, they spent the next three years dealing with their purchase whose details, although never leading to a public dispute, were clearly the source of dissension. Lande took his share in the form of approximately 400 important titles, which for a number of years were known as the LandeArkin Collection. ${ }^{43}$ That he was dissatisfied with his cut was well understood by his associates, hearing his constant lament over not receiving Arkin's particularly fine copy of Captain John Palliser's Exploration...1859-1865, 4v. As for the Arkin duplicates, copies of which were already in the McGill or Lande Collections, from 1964 to 1967 Amtmann maintained "exchange-accounts" which itemized their sale ${ }^{44}$ for a commission and the subsequent purchase of titles that continue to be part of the Arkin and Lande Collections. Included among the purchases are the publications of Edward Blake, along with press release copies of speeches by politicians from the 1960s such as Lucien Saulnier and Prime Minister Lester Pearson - whose appropriateness is a point of continuing debate. In letters dated 28 February, 6 March, 14 and 27 June 1967, on the eve of Archer's departure from McGill to Queen's University, Amtmann and Archer discussed and ultimately agreed upon their mutual satisfaction with the workings of the account, whereby Amtmann had supplied McGill with \$15,716.50 worth of books in exchange for duplicates worth an equivalent amount. Did the exchange account really operate to McGill's benefit? Does this paper trail merely outline a normal business arrangement, or does it attempt to camouflage impropriety and conflict of interest? Only a separate project could adequately address these issues, and then probably with no definitive conclusion. That said, an air of uncertainty, and unanswered questions, continues to linger over the exchange account.

At this juncture, one must pose the question: Why did Lande and Arkin dispose of their Canadiana? Some people have speculated that by virtue of selling their books - Lande having sold some of his collections to McGill and the National Library - they were actually dealers. Although in our age of high taxes many collectors are forced by circumstances to engage in sales and tax dodges, neither man was a dealer. Everything they have said, written, and done points to their passion for collecting. In our egalitarian society, the bequeathing of great research collections to heirs is highly problematic. Will they have the 
interest, the physical space, or the residential stability to house a collection? Sale and dispersal of individual items, or else gift and sale of a coherent collection to a hospitable institution, appear to be the only viable alternatives.

Much is known of the Lande Collections because of their four published catalogues and the three formal agreements with McGill. What of the Arkin Collection? In the beginning, doubts were expressed about its value, and whether it was even worth keeping in McGill's Rare Book Department, due in part to the physical quality of the books being generally less impressive than that of the Lande books. ${ }^{45}$ Of course, the 400 LandeArkin titles were treated as a sub-set of the Lande Collection. The few non-Canadian items became part of the library's general collection of rare books. With the opening of the Lande Room in January 1969, a decision was made to house the Arkin Collection there - partly for convenience, and partly to please Lande. During 1970-1971 the Arkin books - poorly listed on typed and handwritten sheets and paper slips - were finally given main entry cataloguing. In 1972 when the second Lande Collection was acquired, the new agreement specified that the Arkin Collection was a permanent part of the Lande Room and its collections. The 400 Lande-Arkin books were reintegrated into the Arkin Collection, which in the 1990s received full cataloguing. Any talk of dispersing the collection has been put to rest.

What are the strengths, weaknesses, and major characteristics of McGill's Western Canadiana, specifically the titles in the Lande and Arkin Collections? As with most specialized collections, no easy answers are available; rather one must rely upon a combination of qualitative impressions and quantitative measurements. A number of published bibliographies dealing with the West and North provide objective criteria against which McGill's holdings can be evaluated. Although the titles relating to the Arctic and to British Columbia have never been identified, to permit evaluation against relevant bibliographies, the 80 titles relating to the Yukon and the Klondike Gold Rush and the 113 titles relating to the Kootenay Region of British Columbia have been identified and could easily be evaluated against the bibliographies of Berton, ${ }^{46}$ Lotz ${ }^{47}$ and Notre Dame University (Nelson, B.C.). ${ }^{48}$ As for the 97 manuscripts in the Arkin Collection, there are no obvious sources for comparative evaluations.

Only for the three Prairie Provinces - Alberta, Saskatchewan and Manitoba - has a detailed evaluation been undertaken. During 19891991 an alumnae volunteer, Mrs. Katherine Gordon, ${ }^{49}$ compared the McGill holdings in the Lande Room and elsewhere with the 4,370 titles enumerated in the second edition of Peel's Bibliography of the Prairie Provinces. ${ }^{50}$ The results of the comparison are summarized in the accompanying tables. As tables one and two indicate, McGill holds 1,263 titles or 28.9 percent of the Peel titles. Only printed materials are included in this summary, not microforms. Table one shows that apart from the Lande and Arkin Collections, McGill's holdings are quite slim. It also shows that for material published before 1890, Lande and Arkin are equally strong, but thereafter Arkin is stronger. Demonstrated as well is that McGill's strength is much greater for titles published in earlier periods than later: 43.7 percent of the titles published to $1899,23.1$ percent between 1900 and 1939, and only 11 percent between 1940 and 1953.

Comparison with Peel's 23 subject categories appears to have been limited to Lande and Arkin titles, which would explain the discrepancies with the chronological section: In table three, including Peel titles in more than one category would account for his total rising to 5,099; limiting McGill titles to the Lande Room would account for the University's total declining to 1,247 . Table four shows that in terms of the percentage of Peel items held, McGill's top ten categories are: History, Red River Settlement, Rebellions and Regimental Histories, Fur Trade, 
Communications, Explorers Surveyors and Travellers, Journalism, the Environment, Laws and Statues, and Education. Table three shows, however, that there are a number of categories with lower percentages of Peel titles, but with large numbers of titles: The People, Local History, Settling the West, the Spiritual Life, and Literary Works.

These quantitative analyses reveal three additional points of interest. First, the Lande and Arkin Collections contain 105 items not included in the microfilm edition of Peel titles. Second, 32 of the items in the microfilm edition came from McGill. Third, there is a seemingly high proportion of duplicate titles among the various McGill collections. Closer inspection reveals, however, that many so-called duplicates are actually variant printings, new editions, or translations, which Peel will usually list within notes accompanying the first entry of a title but rarely as separate entries. As a result, Mrs. Gordon would carefully note all the McGill copies of a title without necessarily indicating their status. A good example is Peel no. 336, Thomas Spence's Manitoba and the NorthWest... 1871, 46 pages. In his notes, Peel refers to there also being an enlarged 1874 edition and an 1875 French language translation of this early example of Prairie immigration literature. Of the four "duplicate" copies at McGill, Lande no. 1456 is the 1871 edition, Lande no. 1458 is the 1876 edition, and Lande no. 1457 is the 1874 French language edition; only the Arkin copy of the 1871 edition is actually a duplicate. As experienced bibliographers know, only through close investigation can true duplicates be distinguished from variants. A rich resource for investigation is clearly awaiting some future researcher. The ultimate conclusion may well be that few if any of the 303 ostensible duplicates listed in table one are truly duplicates.

In addition to various quantitative measurements, there are also qualitative impressions reported by researchers and other regular users of McGill's Western Canadiana. Publications of British, Canadian, colonial, and provincial governments are well represented. Well represented also are popular works of fiction and nonfiction conveying impressions of the West to mass audiences in Canada and abroad. Concerning British Columbia, the Yukon, and the Arctic only the 18th and 19th century narratives of exploration and discovery possess great strength. As expected, the Prairie material is frequently praised for its richness and variety with specific praise given to: Early discoveries and explorations, the fur trade, railways, the Hudson's Bay Company, missionary activities, the second Riel Rebellion, immigration and early settlements such as the Barr Colony. Particularly impressive is the material relating to: Manitoba, Nathan Arkin's native province, and such related topics as the Red River Settlement, the first Riel Rebellion, and the Manitoba School Question. Finally, Dr. Joyce Banks formerly of the National Library of Canada, has praised the great strength of the Indian language material in the Lande Room. ${ }^{51}$

Another way of looking at McGill's Western Canadiana is to consider the number of items such as books, pamphlets, manuscript items, or biographies in the Lande and Arkin Collections relating to important individuals. The narratives of the following explorers are well represented: Captain George Vancouver (1758-1798) 4 items, William Beresford (fl. 1788) 2 items, Sir Alexander MacKenzie (1765-1820) 11 items, John Palliser (1807-1887) 6 items, and Henry Youle Hind (1823-1908) 10 items. The following political figures are also well represented: Lord Selkirk (1771-1820) 6 items, Louis Riel (18441885) 26 items, and Sir John Christian Schultz (1840-1896) 33 items. Prominent missionaries who are well represented include: Archibishop Alexandre Taché (1823-1894) 37 items, Father Albert Lacombe (1827-1916) 6 items, and Father Adrien Gabriel Morice (1859-1938) 15 items. Among the notable literary authors who are well represented can be found: Ralph Connor 
(1860-1937) 27 items, Ernest Thompson Seton (1860-1946) 12 items, and Nellie McClung (1873-1951) 16 items. Two well represented authors of non-fiction are: Alexander Morris (1826-1889) 20 items, and George Bryce (18481931) 37 items.

A final way of looking at the collections is to consider a small selection of popular immigration and settlement titles from the 1880s and 1890s:

Canada. Department of the Interior. $O n$ the Agricultural Resources of Canada ... 1894. (Arkin Collection).

Pts. I - III: English Tenant Farmers

Pt. IV: Welsh Tenant Farmers

Pt. V: $\quad$ Scottish Tenant Farmers

Pt. VI: An Irish Agricultural Delegate

Pt. VII: Special Report

Canadian Pacific Railway. What Farmers Say about Manitoba, Assiniboia, Alberta, and Saskatchewan, ... 1892. (Arkin Collection).

What Women say of the Canadian North West ... 1886. (Arkin Collection).

Church, Herbert E. Making a Start in Canada.... 1889. (Arkin Collection).

Cockburn, James Seton. Canada for Gentlemen... 1884. (Lande S510).

Goodridge, R.E.W. A Year in Manitoba ... 1882. (Arkin Collection).

Hall, Mary Georgina. A Lady's Life on a Farm in Manitoba... 1884. (Lande 1212).

A number of conclusions can be drawn from this study. The first is that Western Canadiana at McGill has both strengths and weaknesses. Even so, the collection is sufficiently strong that no researcher in the field can afford to ignore it. If curators of other Western collections undertook similar evaluations, ascertaining relative strengths and weaknesses, the comparative strength of various collections could be better ascertained. Another conclusion is that the process by which specialized rare book research collections come into existence requires further investigation. The development of McGill's Western Canadiana revolved around the creative interaction of two collectors, one dealer, and two librarians - with sufficient documentary evidence surviving to provide a coherent picture of this interaction. The replication of this study among other Western Canadian collections would help us to know the unique personalities and local circumstances surrounding each, along with underlying and shared characteristics. The final conclusion is that there is a need to study the social implications surrounding the proliferation of Canadiana collections during the second half of the 20th century. It is hoped that this paper will contribute to an understanding of that much larger phenomenon. 


\section{TABLE ONE}

\begin{tabular}{|c|c|c|c|c|c|c|c|c|c|c|}
\hline 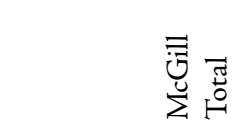 & 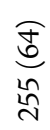 & $\frac{\overparen{\Omega}}{\stackrel{n}{n}}$ & 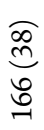 & 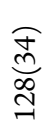 & 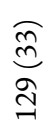 & $\begin{array}{l}\underset{\infty}{\stackrel{D}{d}} \\
\text { o }\end{array}$ & 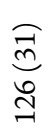 & 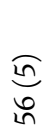 & 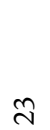 & 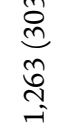 \\
\hline 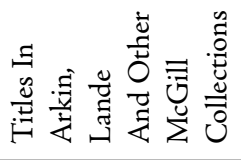 & $\underset{\mathrm{N}}{\overparen{J}}$ & $\frac{\sigma}{m}$ & $\underset{\sim}{\overparen{J}}$ & & & $\underset{-}{\overparen{d}}$ & & & & $\underset{\infty}{\stackrel{\sigma}{\sigma}}$ \\
\hline 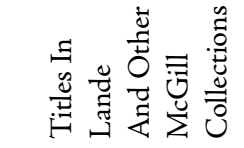 & ๙઼ & $\underset{m}{\tilde{m}}$ & $\underset{\sim}{\overparen{N}}$ & $\underset{\forall}{\stackrel{f}{f}}$ & $\underset{\sim}{\overparen{N}}$ & $\underset{\nearrow}{\Xi}$ & & $\underset{\nearrow}{\Xi}$ & & $\begin{array}{l}\underset{\text { ป }}{\text { ป }} \\
\text { I. }\end{array}$ \\
\hline 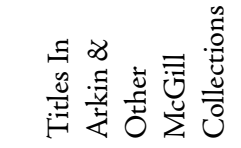 & ๙઼ & $\underset{\wedge}{\mathbb{E}}$ & $\begin{array}{l}\text { હ્} \\
\text { }\end{array}$ & 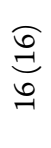 & $\underset{\infty}{\stackrel{\infty}{\rightleftharpoons}}$ & 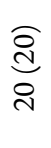 & $\begin{array}{l}\text { ô } \\
\text { en } \\
\text { o }\end{array}$ & $\frac{\widehat{n}}{m}$ & & 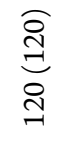 \\
\hline 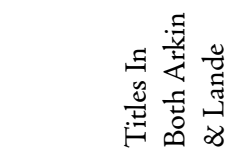 & 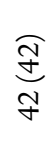 & 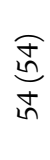 & $\underset{n}{n}$ & $\underset{\stackrel{J}{ \pm}}{\stackrel{\Xi}{J}}$ & 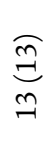 & $\frac{\sqrt{n}}{n}$ & $\underset{\nearrow}{Ð}$ & $\underset{\nearrow}{\Xi}$ & & 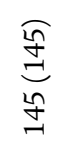 \\
\hline 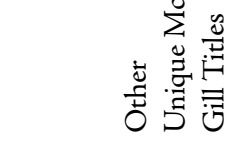 & $\stackrel{m}{m}$ & $\vec{m}$ & $\vec{\sim}$ & \pm & ㄱ & 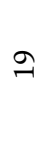 & $\stackrel{\sim}{\sim}$ & $\nabla$ & & $\stackrel{\infty}{\stackrel{\infty}{0}}$ \\
\hline 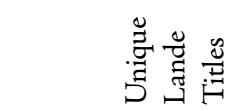 & $\stackrel{2}{1}$ & ๙ & 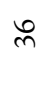 & $\vec{\sim}$ & $\underset{\sqsupset}{\triangle}$ & $\infty$ & & & - & ฟิ \\
\hline 莺泀递 & $\underset{\infty}{+}$ & 2 & $\stackrel{\Re}{\wedge}$ & in & రె & $\hat{n}$ & gิ & F & ন & $\stackrel{\infty}{i}$ \\
\hline 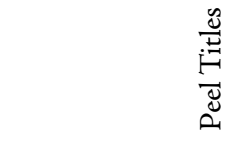 & $\stackrel{\sim}{\mathfrak{n}}$ & $\frac{\widehat{\sigma}}{6}$ & in & $\stackrel{\text { ¿ }}{n}$ & हิ & 祥 & $\stackrel{\infty}{i}$ & $\stackrel{\curvearrowright}{\stackrel{\gamma}{\gamma}}$ & $\stackrel{\infty}{\infty}$ & $\begin{array}{l}\stackrel{R}{n} \\
\stackrel{+}{*}\end{array}$ \\
\hline 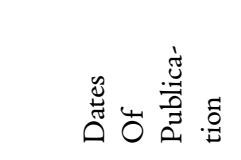 & $\begin{array}{l}2 \\
\infty \\
0 \\
0 \\
1\end{array}$ & $\begin{array}{l}\infty \\
\infty \\
\infty \\
\stackrel{1}{1} \\
\infty \\
\infty \\
\infty \\
-1\end{array}$ & $\begin{array}{l}\stackrel{2}{\infty} \\
\stackrel{1}{-1} \\
\stackrel{2}{\infty} \\
\infty\end{array}$ & 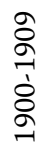 & 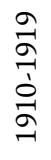 & 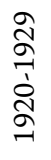 & 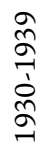 & $\begin{array}{l}\text { gे } \\
\text { ڤे } \\
\text { ò } \\
\text { gे }\end{array}$ & 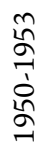 & 突 \\
\hline
\end{tabular}

NOTE: Figures in brackets ( ) indicate the number of duplicate copies. 


\section{TABLE TWO}

The Percentage of Peel Titles Held by McGill According to Time Periods.

$\begin{array}{ll}\text { Published to } 1879 & 49.89 \% \\ 1880-1889 & 44.1 \% \\ 1890-1899 & 36.3 \% \\ 1900-1909 & 25.3 \% \\ 1910-1919 & 21.6 \% \\ 1920-1929 & 22.7 \% \\ 1930-1939 & 22.9 \% \\ 1940-1949 & 11.6 \% \\ 1950-1953 & 12.5 \%\end{array}$




\section{TABLE THREE}

Peel Subject Headings

$\begin{array}{lll}\text { No. of } & \text { No. of } & \begin{array}{l}\text { Percentage of } \\ \text { Peel }\end{array} \\ \text { Titles } & \text { McGill } & \begin{array}{l}\text { Peel titles in } \\ \text { the Lande } \\ \text { Titles }\end{array} \\ & & \begin{array}{l}\text { and Arkin Col- } \\ \text { lections }\end{array}\end{array}$

$\begin{array}{lllll}\text { A. } & \text { The environment } & 104 & 37 & 35.5 \% \\ \text { B. } & \text { The people } & 433 & 116 & 26.7 \% \\ \text { C. } & \text { History } & 54 & 29 & 53.7 \% \\ \text { D. } & \text { History, Local } & 698 & 104 & 14.8 \% \\ \text { E. } & \text { Explorers, Surveyors and Travellers } & 490 & 178 & 36.3 \% \\ \text { F. } & \text { Pro Pelle Cutem (Fur Trade) } & 169 & 73 & 43.1 \% \\ \text { G. } & \text { Red River Settlement } & 92 & 44 & 47.8 \% \\ \text { H. } & \text { Rebellions and Regimental Histories } & 259 & 119 & 45.9 \% \\ \text { I. } & \text { Maintiens le Droit: Roya Canadian } & 32 & 8 & 25.0 \% \\ & \text { Mounted Police } & & & \\ \text { J. } & \text { Communications } & 225 & 82 & 36.4 \% \\ \text { K. } & \text { Settling the West } & 826 & 128 & 15.4 \% \\ \text { L. } & \text { Ranching } & 23 & 4 & 17.3 \% \\ \text { M. } & \text { The Wheat Economy } & 169 & 20 & 11.8 \% \\ \text { N. } & \text { Co-operation } & 59 & 3 & 5.0 \% \\ \text { O. } & \text { Politics and Government } & 218 & 16 & 7.3 \% \\ \text { P. } & \text { Laws, Statues, etc. } & 15 & 5 & 33.3 \% \\ \text { Q. } & \text { Medicine and } & 19 & 1 & 5.2 \% \\ & \text { Nursing } & & & \\ \text { R. } & \text { The Spiritual Life } & 398 & 87 & 21.8 \% \\ \text { S. } & \text { Education } & 145 & 42 & 28.9 \% \\ \text { T. } & \text { Indian languages } & 136 & 33 & 24.2 \% \\ \text { U. } & \text { Literary works } & 509 & 108 & 21.2 \% \\ \text { V. } & \text { Journalism } & 14 & 5 & 35.7 \% \\ \text { W. } & \text { Bibliography } & 5099 & \mathbf{1 2 4 7} & 24.4 \% \\ & \text { TOTAL } & & \end{array}$




\section{TABLE FOUR}

The Percentage of Lande and Arkin Titles According to Peel Subject Headings

\begin{tabular}{|c|c|c|}
\hline 1. & History & $53.7 \%$ \\
\hline 2. & Red River Settlement & $47.8 \%$ \\
\hline 3. & Rebellions and Regimental Histories & $45.9 \%$ \\
\hline 4. & Pro Pelle Cutem (Fur Trade) & $43.1 \%$ \\
\hline 5. & Communications & $36.4 \%$ \\
\hline 6. & Explorers, Surveyors and Travellers & $36.3 \%$ \\
\hline 7. & Journalism & $35.7 \%$ \\
\hline 8. & The Environment & $35.5 \%$ \\
\hline 9. & Laws, Statutes, etc. & $33.3 \%$ \\
\hline 10. & Education & $28.9 \%$ \\
\hline 11. & The People & $26.7 \%$ \\
\hline 12. & $\begin{array}{l}\text { Maintiens Le Droit: Royal Canadian } \\
\text { Mounted Police }\end{array}$ & $25.0 \%$ \\
\hline 13. & Indian Languages & $24.2 \%$ \\
\hline 14. & The Spiritual Life & $21.8 \%$ \\
\hline 15. & Literary Works & $21.2 \%$ \\
\hline 16. & Ranching & $17.3 \%$ \\
\hline 17. & Settling the West & $15.4 \%$ \\
\hline 18. & History, Local & $14.8 \%$ \\
\hline 19. & The Wheat Economy & $11.8 \%$ \\
\hline 20. & Politics and Government & $7.3 \%$ \\
\hline 21. & Medicine and Nursing & $5.2 \%$ \\
\hline 22. & Co-operation & $5.0 \%$ \\
\hline 23. & Bibliography & $4.6 \%$ \\
\hline
\end{tabular}




\section{ENDNOTES}

${ }^{1}$ The author wishes to express his appreciation to the following individuals and institutions for their assistance in writing this paper: Ms. Linda Hoad and Dr. Joyce Banks, Special Collections, National Library of Canada; Dr. Robert H. Michel, McGill University Archives; Mrs. Nellie Reiss, Lande Librarian, and Mr. Bruce Whiteman, Department of Rare Books and Special Collections, McLennan Library, McGill University; Mr. David Bourke, Secretary-General, McGill University; and Mr. Harold Arkin for permission to consult papers relating to his father at McGill University and the National Library of Canada. The following abbreviations have been used: MRBD, McGill University, McLennan Library, Department of Rare Books and Special Collections; MUA, McGill University Archives; NLC, National Library of Canada, Ottawa. An abbreviated version of this article was published as "Western Canadiana at McGill University: the Formation of a Rare Book Collection." In Libraries \& the Cultural Record: Exploring the History of Collections of Recorded Knowledge, v. 43, no. 2 (Spring, 2008) p. 176-192 University of Texas Press.

${ }^{2}$ Canada. National Library. Directory of Special Collections of Research Value in Canadian Libraries. Ottawa, Supply and Services, 1992, xi, 204, xii, 220p.

${ }^{3}$ Ernest B. Ingles, The Margaret Hess Collection. rev. ed. Calgary, University of Calgary, Special Collections, 1991. 19 p. (Occasional Paper, no.3).

${ }^{4}$ Arctic Institute of North American. Library. Catalogue. Boston, Hall, 1968. 4v. (plus 5 volumes of supplements).

${ }^{5}$ British Columbia. Archives. Dictionary Catalogue of the Library. Boston, Hall, 1971. 8v.

${ }^{6}$ Glenbow-Alberta Institute Library. Catalogue of the Glenbow Historical Library. Boston, Hall, 1973. 4v.

${ }^{7}$ Mount Allison University. Library. The Edgar and Dorothy Davidson Collection of Canadiana... Sackville, Centre for Canadian Studies, 1991. xxiv, 418p.

${ }^{8}$ Patricia Belier, "A Box of Pamphlets:" a Checklist of the Isaac Burpee Collection of Westerniana. Archives and Special Collections, Harriet Irving Library, University of New Brunswick, 1996. iii, 47p.

${ }^{9}$ Information supplied by Mme. Genevieve Bazin, Université de Montréal.

${ }_{10}$ Toronto Public Library. A Bibliography of Canadiana... Toronto, Library, 1935-1989. 6v.

11 ....... The Canadian NorthWest: A Bibliography... Toronto, Library, 1931.52p.

12 Peter F. McNally, "McGill University Libraries." International Dictionary of Library Histories, ed. by David Stam. Chicago, Fitzroy Dearborn, 2001 v. 1, p. 436-438.

13 "Lawrence M. Lande." Canadian Who's Who. Toronto, University of Toronto Press. v. XXIX (1994), p. 638-639; "Lawrence Montague Lande." A personal information card with a photographic portrait, presented by the International
Biographical Centre of Cambridge, England. Circa 1975, MRBD, "Dr. Lande;" Catherine M. Draper, "The accent is in diversity...bursting with life."' Mss 12 pages, copies to be found in MRBD and NLC Amtmann papers.

${ }^{14}$ McGill University. Libraries. A Catalogue of the Lawrence Lande William Blake Collection... Montreal. McLennan Library, 1983. xii, 172, [7]p.

${ }^{15}$ Lawrence M. Lande, Old Lamps Aglow: an Appreciation of Early Canadian Poetry. Montreal, Christian Brothers, 1957. xiv, 329p.

${ }^{16}$ Ernest B. Ingles, Bibliography of Canadian Bibliographies. 3rd ed. Toronto, University of Toronto Press, 1994. xliii, 1178 p. (15 items are listed).

${ }_{17}$ Université de Montréal. Catalogue de la Collection de Canadiana Louis Melzack. Montreal, Université de Montréal, Bibliothèque, 1988.3v; (See also footnote \# 7)

18 "Nathan Arkin." The Jewish Post and News. (February 17, 1988), p. 18; ....... Winnipeg Free Press, (January 31, 1988), p. 26; Information also supplied by Mr. Harry Gutkin, President, and Ms. Bonnie Tregobov, Archivist, Jewish Historical Society of Western Canada, Winnipeg, and by Mr. Jim Blanchard, University of Manitoba Library.

${ }^{19}$ Harry Arkin, Ethics as Legislation. Cambridge, Mass., Sciart Publishers, 1945. 256p.

${ }^{20}$ Bruce B. Peel, A Bibliography of the Prairie Provinces to 1953, Supplement. Toronto, University of Toronto Press, 1963. p. v.

${ }^{21}$ John Mappin and John Archer, Bernard Amtmann, $1907-$ 1979; a Personal Memoir. Ottawa, Amtmann Circle, 1987. $73 \mathrm{p}$.

${ }^{22}$ Peter F. McNally, "Scholar Librarians: Gould, Lomer,and Pennington." Fontanus: from the Collections of McGill University, v. I (1988), p. 95-104.

23 ........ Identical Cousins: Richard Pennington and David Peterley; the Story of Peterley Harvest." Papers of the Bibliographical Society of Canada. v. XXVI (1987), p. 66-87.

${ }^{24}$ Richard Pennington, A Descriptive Catalogue of the Etched Work of Wenceslaus Hollar, 1607-1677. Cambridge, Cambridge University Press, 1982. lxiv, 452p.

${ }^{25}$ MUA. RG40, Library. “Old Lamps Aglow,” C44, F. 4373, 4374, 4375. There are separate files devoted to Lande throughout the Pennington papers.

26 "John H. Archer." Canadian Who's Who. Toronto, University of Toronto Press, v. XXIX (1994), p. 28; “Dr. John Hall Archer, O.C.,S.O.M. (1914-2004).“ Saskatchewan History. v. 56 (Spring, 2004), p. 3; Personal Information.

${ }^{27}$ NLC. Bernard Amtmann Fonds. Unit I, Alphabetical Files, “John Archer," F. 16-20.

${ }^{28}$ John G. Diefenbaker. One Canada: Memoirs... Toronto, Macmillan, 1975-1977.3v.

${ }^{29}$ MUA. RG4. Board of Governors. "Lande Donation 1963 1975." C. 433, File 07938. C. 503, File 06782. 
${ }^{30}$ Lawrence M Lande, The Lawrence Lande Collection of Canadiana in the Redpath Library of McGill University, a Bibliography. Montreal, McGill University Press, 1965. xxxv, 301p.

31 ....... Rare and Unusual Canadiana: First Supplement to the Lande Bibliography. Montreal, Lawrence Lande Foundation for Canadian Historical Research, 1971. xx, 779p.

32 ....... The Moravian Missions to the Eskimos of Labrador; a Checklist... Montreal, Lawrence Lande Foundation for Canadian Historical Research, 1973. 32p.

33 .....-. A Checklist of Printed and Manuscript Material Relating to the Canadian Indian, also Relating to the Pacific NorthWest Coast. Montreal, Lawrence Lande Foundation for Canadian Historical Research, 1974. 82p.

${ }^{34}$ NLC. Bernard Amtmann Fonds. Unit I, Alphabetical Files, "Nathan Arkin," F. 24.

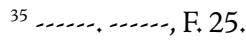

36 _............, F. 27.

37 _...-., "John Archer," F. 20.

38 ......, “McGill University. Western Canada Project," F. 4.

39 ......, “Nathan Arkin," F. 25. Invoice \#16507.

40 ....... "McGill University. Western Canada Project," F. 6. Amtmann to Archer, February 28, 1967.

41 ....... “Nathan Arkin," F. 25. Amtmann to Arkin, May 15, 1965.
42 _..........., F. 26, 27, 28.

43 MRBD. "Arkin Notes, Correspondence, and Orders." Memo by Mrs. Carroll, May 23, 1967.

${ }^{44}$ NLC. Amtmann Fonds. "McGill University. Western Canada Project," F. 6. MRBD. "List of Exchanges Acquired for Arkin Collection from B. Amtmann's." Memo by John Archer, June 9, 1967.

45 MRBD. "Notes, Correspondence, and Orders," and "Arkin."

${ }^{46}$ Pierre Berton, A Klondike Bibliography. Kleinburg, Ont. n.p., 1958, 23p.

47 Jim Lotz, Yukon Bibliography. Ottawa, Department of Northern Affairs and National Resources, 1964. vii, 155p.

${ }^{48}$ Notre Dame University of Nelson. Library. Kootenaiana: a Listing of Books... Nelson, B.C., Notre Dame University Library, 1976. 167p.

49 Although Mrs. Gordon undertook the comparison of McGill's holdings with Peel's chronological section, the comparison with Peel's subject section appears to have been done by a McGill library staff member, Mrs. Janet Sader.

${ }^{50}$ Bruce B. Peel, A Bibliography of the Prairie Provinces to 1953.... 2nd ed. Toronto, University of Toronto Press, 1973. xxviii, 780p.

${ }^{51}$ Told to the author during an interview, July 1994. 
